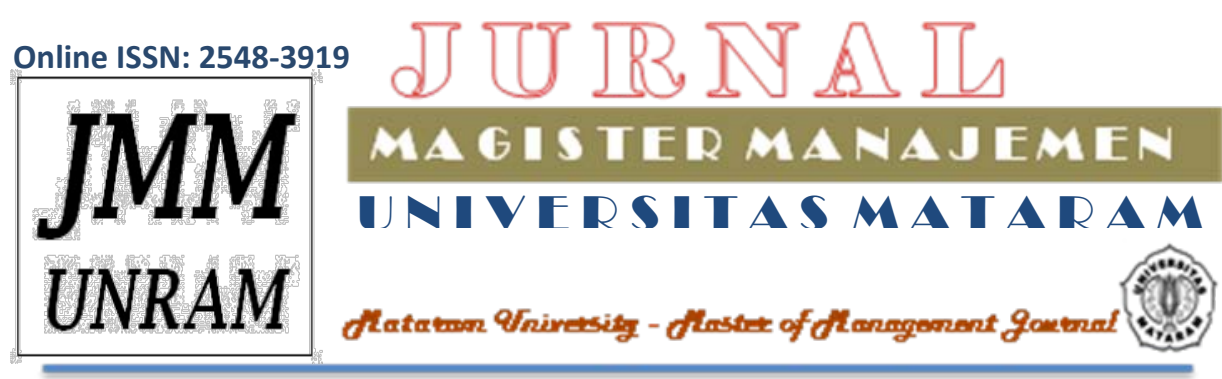

\title{
PENGARUH INFORMATIVENESS, ENTERTAINMENT, DAN IRRITATING TERHADAP ATTITUDE TOWARD SOCIAL MEDIA ADVERTISING PADA MASYARAKAT KOTA MATARAM
}

\author{
Yeldy Dwi Genadi', Lalu M. Furkan ${ }^{2}$ \\ 1Program Studi Magister Manajemen Fakultas Ekonomi dan Bisnis Unram, \\ yeldygenadi86@gmail.com \\ 2Fakultas Ekonomi dan Bisnis, Universitas Mataram
}

\section{ARTICLE INFO}

Keywords :

Social Media

Informativeness,

Irritation, Attitude.

Kata Kunci :

Iklan Media Sosial, Informativeness, Hiburan, Iritasi, Sikap.

How to cite :

Genadi, Yeldy Dwi., Furkan, Lalu M., (2020). Pengaruh Informativeness, Entertainment, dan Irritating Terhadap Attitude Toward Social Media Advertising Pada Masyarakat Kota Mataram, 9(2), 186-197

DOI :

http://dx.doi.org/10.29303/jmm.v9i2.538

Dikumpulkan : 10 Juni 2020

Direvisi : 17 Juni 2020

Dipublikasi : 24 Juni 2020

\section{ABSTRACT}

This research aimed to analyze the influencing of attitude toward social media advertising that is informativeness, entertainment, and irritation. This research was using the appliance of data taken (instrument) in the form of questionaire laying open about informativeness, entertainment, and irritation. So that data taken by good hence questionaire have to be up to standard of validity and reliability. Analysis technique used at this research was multiple linier regression analysis to know the accurate independent variable influencing toward dependent variable. As for multiple linier regression model have to be up to standard of public assumption of regression by conducting classical assumption test. Pursuant to result of multiple linier regression analysis proven by that independent variable in the form of informativeness (X1), entertainment (X2), and irritation (X3) have the influence which significant to dependent variable by that is attitude toward social media advertising. While based on result the $t$ test proven by that independent variable by partially have an effect on by significant to dependent variable, so that hypothesis at this research was fully supported. Independent variable which is dominant influencing to the attitude toward social media advertising is entertainment.

Penelitian ini bertujuan untuk meneliti variabel yang mempengaruhi attitude toward social media advertising yaitu informativeness, entertainment, dan irritation. Penelitian ini menggunakan alat pengumpulan data (instrumen) berbentuk kuesioner yang mengungkapkan mengenai informativeness, entertainment, dan irritation. Dengan demikian data yang diambil dengan kuesioner harus bermutu baik, memenuhi syarat validitas dan reliabilitas. Teknik analisis data yang digunakan pada penelitian ini adalah analisis regresi linier berganda yang bertujuan untuk mengetahui ketepatan pengaruh variabel 
bebas terhadap variabel terikat. Model regresi linier berganda harus bermutu baik, memenuhi syarat untuk pengambilan keputusan dengan melakukan uji asumsi klasik. Berdasarkan hasil analisis regresi linier berganda terbukti bahwa variabel bebas seperti informativeness (X1), entertainment (X2), dan irritation (X3) mempunyai pengaruh yang signifikan terhadap variabel terikat. Sedangkan berdasarkan hasil pada uji t terbukti bahwa variabel bebas secara parsial berpengaruh signifikan terhadap variabel terikat, sehingga dengan demikian hipotesis pada penelitian ini terdukung sepenuhnya. Variabel bebas yang dominan mempengaruhi attitude toward social media advertising adalah variabel entertainment.

Copyright (C) 2020 JMM Unram. All rights reserved.

\section{PENDAHULUAN}

Perkembangan marketing dalam ilmu komunikasi, berupa Integrated Marketing Communicationyang terdiri dari advertising, public relations, personal selling, promotion dan direct marketing kini mulai berkembang dalam 10 tahun terakhir melalui website dan jejaring sosial yang juga sering disebut social media. Iklan telah berubah dengan cepat dari tahun ke tahun dalam kaitannya dengan teknologi dan teknik terbaru (Richards dan Curran, 2002). Iklan sebagai salah satu alat komunikasi pemasaran bertumbuh sangat cepat (Shavitt et al, 1998). Keseluruhan proses ini akan mempengaruhi attitude orang terhadap bagaimana fenomena penggunaan social media dalam marketing. Attitude digambarkan sebagai kecenderungan psikologis yang ditunjukkan melalui evaluasi terhadap beberapa hal dengan skala suka atau tidak suka (Eagly dan Chaikan, 1993), dan dapat mempengaruhi minat (Ajzen dan Fishbein, 1980).

Attitude Toward Advertising adalah merupakan sikap seseorang terhadap keberadaan sebuah periklanan (Simamora, 2008). Penelitian yang dilakukan oleh Mittal (1994) dan Muehling (1987) memperlihatkan bahwa media tradisional memiliki pengaruh negatif terhadap sikap terhadap periklanan. Namun di sisi lain penelitian menunjukkan pentingnya sikap pada pandangan konsumen (Lutz, 1985; Mac Kenzie et al, 1986; Muehling, 1987). Leppaniemi et al (2006) menyatakan bahwa riset mobile marketing yang telah dilakukan selama ini difokuskan terutama pada faktor-faktor yang berhubungan dengan pembelajaran konsumen. Sikap khusus konsumen terhadap mobile marketing telah mendapatkan cukup banyak perhatian dalam riset pemasaran (Tsang et al, 2004). Fenomena ini menunjukkan bagaimana jejaring sosial telah telah membawa komunikasi antar manusia menuju ke era digital (Torres, 2008). Selain itu, penelitian saat ini difokuskan terutama pada anteseden sikap seperti Entertainment (hiburan), Informativeness (keinformatifan), Irritating (gangguan), dan Credibility (kredibilitas) (Tsang et al, 2004).

Keng dan Ting (2009), menemukan bahwa entertainment secara positif mempengaruhi sikap konsumen dalam menerima pesan karena hal ini rasa interaksi dalam diri. Sementara Scharl et al (2005) membuktikan bahwa entertainment dan informativeness dapat secara positif mempengaruhi minat beli terhadap produk yang diiklankan. Penelitian yang dilakukan oleh Brackett dan Carr (2001) menunjukkan bahwa umumnya iklan di media sosial dan internet bisa sangat mengganggu dan kurang efektif. Lebih lanjut lagi, banyak blog, forum diskusi, dan artikel online lainnya menyatakan bahwa iklan di media 
sosial tidak akan dapat berhasil (Uphoff, 2009; Bgamal, 2009 Porter, 2008; Stern, 2008). Informativeness dan entertainment merupakan bagian yang kuat dalam iklan di internet menurut para responden (Ducoffe, 1996). Sikap konsumen terhadap iklan internet menunjukkan bahwa informativeness, entertainment, irritating dan nilai sebuah iklan dapat mempengaruhi sikap konsumen (Ducoffe, 1996).

Chowdhury et al (2006) meneliti faktor yang mempengaruhi penerimaan konsumen terhadap mobile advertising di Banglades, menyimpulkan bahwa dari entertainment, informativeness, irritating, dan credibility, hanya credibility yang memiliki suatu dampak penting pada sikap terhadap mobile advertising. Entertaiment merupakan faktor yang penting dalam iklan melalui media sosial. Ini adalah inti dari pesan yaitu ringkas, lucu dan dapat dengan cepat mendapatkan perhatian dari konsumen. Pelayanan entertaiment dapat meningkatkan kesetiaan konsumen dan menambah nilai bagi konsumen itu sendiri. Mengirimkan games dan hadiah untuk target pelanggan suatu provider celuller adalah salah satu cara yang berhasil dalam menarik dan menjaga pelanggannya (Haghirian dan Madlberger, 2004).

Selain itu, advertising memainkan peranan penting dalam pemberian informasi (Ling dan Piew, 2010). Tidak asing lagi peran informativeness dalam pemberian informasi pada iklan memiliki hubungan yang kuat terhadap advertising value saat dilakukan transfer informasi melalui media ponsel. Keuntungan dari penyampaian iklan kepada konsumen ini bertujuan agar konsumen dapat memiliki pengaruh secara tidak langsung dalam menilai keefektifan dari sebuah iklan (Younes, 2011). Irritating adalah unsur berupa penggunaan teknik-teknik mengganggu, memanipulasi, menyerang serta menghina pihak lain dalam iklan (Ducoffe,1996). Dengan kata lain iklan bisa dikatakan mengganggu apabila menggunakan teknik-teknik yang bersifat memanipulasi atau bahkan menyerang pihak lain.

Melakukan penjualan melalui sosial media oleh beberapa perusahaan dirasa cukup beralasan. Hal ini tentu mengacu pada survey yang dilakukan oleh PusKaKom UI pada tahun 2015 yang menunjukkan bahwa 85 persen penduduk Indonesia mengakses Internet menggunakan telepon seluler mereka. Dari 5 hal yang sering diakses oleh para pengguna internet tersebut, mengakses sosial media berada diurutan terdepan, diikuti dengan mengakses pesan singkat diurutan selanjutnya.Sikap khusus konsumen terhadap mobile marketing telah mendapatkan cukup banyak perhatian dalam riset pemasaran (Tsang et al, 2004).

Dari berbagai hasil penelitian di atas, dapat dilihat bahwa antara satu variabel dengan variabel lainnya menunjukkan pengaruh yang tidak sama terhadap variabel attitude toward social media advertising sehingga dibutuhkan penelitian yang mungkin dapat memperlihatkan perspektif berbeda dengan penelitian sebelumnya.

\section{KAJIAN PUSTAKA}

Social Media Advertising adalah salah satu bentuk marketing dengan menggunakan konsep Social Media. Memasarkan (marketing) sesuatu (product, brand, issue, etc) menggunakan tools-tools social media dengan memanfaatkan masyarakat yang turut berpartisipasi di sosial media' dalam kampanyenya. Beberapa hal penting dalam social media marketing adalah Mencari Customer menyebarkan awareness, menjadi pengaruh (influencer), menunjukkan awareness dari sudut pandang lain, serta melakukannya dengan kontinyu. Aplikasi paling lumrah dari social media marketing adalah corporate blog. Jadi 
menggunakan blog sebagai media public relation untuk memberitahukan kepada khalayak ramai terkait hal-hal yang perlu mereka ketahui.

Ducoffe (1996) mengatakan bahwa entertaining adalah "the ability to fulfill audience needs for escapism, divertion, aesthetic enjoyment, or emotional release". Dari definisi tersebut, entertaining adalah kemampuan sebuah iklan dalam memenuhi keinginan pemirsa untuk mendapatkan hiburan, estetika kesenangan, maupun pelepasan emosi. Secara umum memang banyak iklan-iklan yang sifatnya memberikan hiburan sambil menyisipkan informasi-informasi mengenai produk yang diiklankan. Melalui pengertian di atas dapat disimpulkan bahwa iklan merupakan suatu strategi yang digunakan oleh suatu perusahaan dalam mempromosikan produk mereka untuk menarik minat konsumen terhadap produk yang ditawarkan. Dengan iklan tersebut, perusahaan mampu menstimulus konsumen dengan mempengaruhi pikiran, perasaan, dan tindakan.

Peran utama dari iklan adalah untuk membangkitkan kesadaran produk dan membuat konsumen menyadari bagaimana produk yang berbeda dapat bersaing. Salah satutujuan periklanan adalah untuk menginformasikan konsumen tentang produk baru atau fitur baru dari produk yang ada, juga membuat konsumen menyadari perubahan harga produk (Kotler dan Keller, 2006). Lebih lanjut dikatakan Ducoffe (1996), informativeness berarti "the ability of advertising to inform consumers of product alternatives so that purchases yielding the greatest possible satisfaction can be made". Dari sini dapat diketahui bahwa informativenes sadalah kemampuan dari sebuah iklan dalam menginformasikan kepada konsumennya mengenai alternatif-alternatif produk yang diproduksinya sehingga dalam melakukan pembelian konsumen mendapatkan kepuasan dari produk tersebut. Pendapat lain dikemukakan oleh Sutabri (2005:23) bahwa Informasi adalah data yang telah diklasifikasikan atau diolah atau di interprestasi untuk digunakan dalam proses pengambilan keputusan.Sutabri (2005:31) menambahkan, Nilai informasi ditentukan oleh dua hal, yaitu manfaat dan biaya untuk mendapatkan informasi tersebut. Suatu informasi dapat dikatakan bernilai bila manfaatnya lebih efektif dibandingkan dengan biaya untuk mendapatkannya. Sebagian besar informasi tidak dapat ditaksir secara pasti nilai keuntungannya (dalam satuan uang), tetapi kita dapat menaksir nilai efektifitas dari informasi tersebut.

Hal lain yang mempengaruhi attitude toward social media advertising adalah irritating. Wells et al (2003) mengatakan bahwairritating adalah "advertising as those that cause displeasure and momentary impatience". Dari definisi tersebut, irritating adalah sebuah iklan yang dirasakan menyebabkan konsumen menjadi tidaknyaman. Respon yang diberikan untuk irritating ini bisa lebih negatif daripada sekedar rasa tidak suka. Penelitian mengenai irritating ini mengungkapkan bahwa penyebab terbesar dari ketidaksukaan terhadap suatu iklan adalah dikarenakan produknya itu sendiri. Ketika iklan mengganggu, maka akan mengakibatkan gangguan, yang pada gilirannya akan memiliki efek negatif pada sikap dan pengaruh terhadap perilaku konsumen. Irritating juga bisa menyebabkan kekuatan persuasif dari sebuah iklan berkurang. Konsumen sering melihat iklan sebagai gangguan dalam hidup merekayang merupakan akar ketidakpuasan dan menciptakan sikap negatif terhadap iklan atau suatu merek. Untuk menciptakan sikap positif terhadap iklan, pengiklan harus menghindari irritating konsumen karena memiliki efek negatif pada sikap secara keseluruhan. Penelitian telah menunjukkan bahwa salah satu sumber utama dari irritating adalah bahwa taktik yang digunakan oleh pengiklan yang mengganggu, menghina atau terlalu memanipulasi. Hal ini akan mengakibatkan kemungkinan besar konsumen akan melihat iklan tersebut sebagai pengaruh negatif yang tidak diinginkan dan 
menjengkelkan bagi konsumen. Oleh karena itu, sikap konsumen terhadap mobile advertising akan terpengaruh secara negatif oleh irritating (Ducoffe, 1996).

Variabel informativeness, irritation, dan credibility berpengaruh terhadap sikap masyarakat, sedangkan variabel entertainment tidak signifikan memengaruhi sikap masyarakat (Budiarto, 2014). Variabel entertainment yang tidak memiliki pengaruh signifikan lebih dikarenakan oleh perbedaan budaya, adat istiadat, tingkat pendidikan, dan penghasilan responden penelitian. Seperti diketahui bahwasanya orang Indonesia pada umumnya dan masyarakat di Kota Mataram pada khususnya tidak memiliki minat membaca yang tinggi, sehingga iklan SMS yang berupa tulisan belaka tidak mampu untuk menghibur mereka (Budiarto, 2014). Karakteristik masyarakat pengguna telepon seluler di Kota Mataram hampir mirip dengan keadaan masyarakat di India, sebagaimana temuan dalam penelitian Badiyani (2013).

Temuan penelitian Le dan Nguyen (2014) menunjukkan bahwa meskipun banyak pengguna tidak memiliki perasaan positif terhadap iklan, mereka tidak dapat mengabaikan pentingnya iklan seluler. Jika pengiklan seluler dapat menghadirkan kredibilitas dan hiburan dalam iklan mereka, konsumen bersedia untuk melihat iklan dan dipengaruhi untuk membeli produk dan layanan. Seperti halnya online marketing sangat berpengruh terhadap sikap masyarakat karena memberikan banyak informasi (Achmad, 2014). Temuan El Ashmawy dan El Sahn (2014) dalam penelitiannya menunjukkan bahwa kredibilitas memiliki efek tertinggi pada sikap terhadap periklanan melalui media sosial Facebook. Selanjutnya ditemukan juga variabel yang paling tidak signifikan adalah variabel irritation (gangguan).

Berdasarkan hasil penelitian Achmad (2014) diketahui bahwa variabel online marketing Facebook yang terdiri dari Hadirnya Iklan, Konformitas, dan Gaya Hidup berkontribusi besar dalam membentuk Perilaku Konsumsi pada siswa SMA di Kota Mataram. Hal ini menunjukkan bahwa jika terjadi perubahan baik itu peningkatan ataupun penurunan pada variabel bebas (Hadirnya Iklan, Konformitas, dan Gaya Hidup), maka akan menyebabkan perubahan pula secara searah/berbanding lurus terhadap variabel terikat dalam hal ini adalah Perilaku Konsumsi siswa SMA di Kota Mataram. Hadirnya Iklan merupakan variabel yang dominan berpengaruh terhadap Perilaku Konsumsi telah dibuktikan dalam penelitiannya.

\section{METODE PENELITIAN}

Penelitian ini termasuk penelitian asosiatif yang dijelaskan melalui pendekatan penelitian kuantitatif. Penelitian asosiatif adalah suatu metode yang bertujuan untuk mengetahui hubungan antara dua variabel atau lebih. Dengan penelitian ini maka akan dapat dibangun suatu teori yang berfungsi untuk menjelaskan, meramalkan dan mengontrol suatu gejala. Penelitian ini bertujuan untuk mengetahui pengaruh antara faktor informativeness, entertainment, dan irritating terhadap attitude towards social media advertising pada masyarakat Kota Mataram.

Metode sampling yang digunakan dalam penelitian adalah non probability sampling dengan teknik convenience sampling. Non probability samplingmerupakan cara pengambilan sampel yang cenderung berdasarkan pertimbangan subyektif peneliti sehingga populasi tidak memiliki kesempatan sama untuk terpilih sebagai responden (Malhotra, 2007). Penggunaan pendekatan sampling ini didasarkan juga pada pertimbangan jumlah populasi yang tidak diketahui (infinite population). Oleh karenanya pengambilan sampel 
berdasarkan teori yang dikemukakan oleh Roscoe (1975) dalam Sekaran (2006) dengan jumlah sampel antara 30 sampai 100 orang.

Masyarakat Kota Mataram yang menjadi sampel penelitian ini adalah pengguna aktif media sosial. Penelitian ini sebelumnya telah melakukan uji validitas untuk mengetahui pernyataan-pernyataan yang terdapat dalam kuesioner sesuai atau tidak dengan apa yang akan diukur dengan langkah awal menyebar kuesioner sebanyak 30 buah. Penjelasan hasil uji validitas dari penelitian ini dapat dilihat dalam pembahasan uji kualitas instrumen. Karena hasil uji instrumen dinyatakan valid maka selanjutnya diperoleh karakteristik responden meliputi jenis kelamin, umur, tingkat pendidikan, dan banyaknya jenis sosial media yang digunakan. Selanjutnya kuesioner disebar kepada masyarakat Kota Mataram lainnya sebanyak 70 buah untuk mencukupi kuota sampel dalam penelitian ini.

Untuk menguji hipotesis yang telah diajukan sebelumnya, maka digunakan alat analisis regresi linier berganda.

\section{HASIL DAN PEMBAHASAN}

\subsection{Analisis Data}

Analisis regresi linier berganda dilakukan dalam rangka uji model untuk mengetahui apakah variabel informativeness $\left(X_{1}\right)$, entertainment $\left(X_{2}\right)$, dan irritating $\left(X_{3}\right)$ mempunyai pengaruh yang signifikan terhadap Attitude towards Social Media Advertising pada Masyarakat Kota Mataram (Y). Untuk mengetahui besarnya variasi perubahan variabel bebas terhadap variasi perubahan variabel terikat Attitude towards Social Media Advertising pada Masyarakat Kota Mataram dapat diketahui dari nilai koefisien determinasi Adjusted $R$ Square $\left(\mathrm{R}^{2}\right)$ sebagaimana yang ditunjukkan pada tabel berikut ini :

Tabel 1. HasilModel Summary

\begin{tabular}{ccccc}
\hline Model & $\boldsymbol{R}$ & $\boldsymbol{R}$ Square & $\begin{array}{c}\text { Adjusted } \boldsymbol{R} \\
\text { Square }\end{array}$ & $\begin{array}{c}\text { Std. Error of } \\
\text { the Estimate }\end{array}$ \\
\hline 1 & 0,901 & 0,812 & 0,807 & 0,33428 \\
\hline
\end{tabular}

Besarnya nilai Adjusted R Square pada tabel Model Summary di atas adalah 0,807. Hal ini berarti 80,70 persen variabel Attitude towards Social Media Advertising pada Masyarakat Kota Mataram dapat dijelaskan oleh ketiga variabel bebas dalam penelitian ini, yaitu variabel informativeness, entertainment, dan irritating. Sedangkan sisanya sebesar 19,30 persen dijelaskan oleh variabel-variabel yang lain di luar model penelitian ini. Hal ini berarti bahwa faktor-faktor kualitas dan kuantitas informasi, daya tarik iklan serta irritating yang ada pada periklanan di Kota Mataram mampu menjelaskan Attitude towards Social Media Advertising.

Tampak pada Tabel 1, semakin kecil varians error maka semakin besar nilai koefisien determinasi yang dihasilkan. Sebaliknya, semakin besar varians error maka semakin kecil nilai koefisien determinasi model regresi linier yang dihasilkan. Varians error menggambarkan variasi data secara langsung, semakin besar variasi data penelitian akan berdampak pada semakin besar varians error. Rancangan kuesioner yang tidak reliabel, teknik wawancara/pengumpulan data semuanya mempunyai kontribusi pada variasi data yang dihasilkan. Pada survei dengan skala besar yang dilakukan, sumber variasi bisa disebabkan oleh perbedaan pemahaman responden dalam menangkap maksud item pertanyaan dalam kuesioner yang disampaikan oleh peneliti. 
Berdasarkan hasil analisis regresi linier berganda tersebut, dengan melihat nilai Standardized Coefficients Beta masing-masing variabel bebas, maka dapat diketahui variabel yang memiliki pengaruh paling dominan terhadap Attitude towards Social Media Advertising pada Masyarakat Kota Mataram adalah variabel entertainment $\left(\mathrm{X}_{2}\right)$. Pernyataan ini didukung oleh hasil Standardized Coefficients Beta yang terbesar terdapat pada variabel entertainment sebesar 0,835 jauh lebih besar jika dibandingkan dengan Standardized Coefficients Beta variabel informativeness $(0,437)$ serta variabel irritating $(-0,210)$.

Uji Goodness of Fit digunakan untuk menguji kelayakan model yang digunakan dalam penelitian. Uji F signifikan maka model layak untuk diteliti, atau model fit. Dikatakan layak apabila data fit (cocok) dengan persamaan regresi. Goodness of Fit dalam penelitian ini terkait pengaruh variabel informativeness $\left(X_{1}\right)$, entertainment $\left(X_{2}\right)$, dan irritating $\left(\mathrm{X}_{3}\right)$ terhadap Attitude towards Social Media Advertising pada Masyarakat Kota Mataram (Y) dapat dilihat dari nilai uji $\mathrm{F}$ analysis of variance (ANOVA).Dari hasil pengujian ANOVA untuk uji F dapat disajikan pada tabel berikut ini:

Tabel 2. HasilAnalysis of Variance (ANOVA)

\begin{tabular}{ccccccc}
\hline \multirow{2}{*}{ Model } & $\begin{array}{c}\text { Sum of } \\
\text { Squares }\end{array}$ & df & Mean Square & $\boldsymbol{F}$ & Sig. \\
\hline \multirow{4}{*}{1} & Regression & 46,472 & 3 & 15,491 & 138,631 & 0,000 \\
& Residual & 10,727 & 96 & 0,112 & & \\
& Total & 57,199 & 99 & & & \\
\hline
\end{tabular}

Pada tingkat kepercayaan 95 persen $\left(\alpha=5\right.$ persen) diperoleh nilai $F_{\text {tabel }}$ sebesar 2,700 sedangkan nilai $F_{\text {hitung }}$ sebesar 10,914. Dengan demikian nilai $F_{\text {hitung }}$ lebih besar dari $F_{\text {tabel }}$ dengan nilai signifikansi sebesar 0,000 yang lebih kecil dari syarat ketentuan signifikan sebesar 0,050. Ini berarti bahwa variabel informativeness, entertainment, dan irritatingsecara simultan berpengaruh signifikan terhadap Attitude towards Social Media Advertising pada Masyarakat Kota Mataram. Berdasarkan hasil uji ini menyatakan bahwa model penelitian ini telah memenuhi kelayakan untuk diteliti, atau model penelitian dinyatakan fit.

Pengujian ini digunakan untuk mengetahui pengaruh masing-masing variabel bebas/independen secara sendiri-sendiri (parsial) terhadap variabel dependen dalam penelitian ini yaitu Attitude towards Social Media Advertising pada Masyarakat Kota Mataram. Hasil uji model tersebut dapat dilihat berdasarkan Tabel 3 berikut:

Tabel 3. Uji Model Pengaruh Informativeness, Entertainment, dan Irritating terhadap

Attitude towards Social Media Advertising pada Masyarakat Kota Mataram

\begin{tabular}{ccccccc}
\hline \multirow{2}{*}{ Model } & \multicolumn{2}{c}{$\begin{array}{c}\text { Unstandardized } \\
\text { Coefficients }\end{array}$} & $\begin{array}{c}\text { Standardized } \\
\text { Coefficients }\end{array}$ & \multirow{2}{*}{ Sig. } \\
\cline { 3 - 5 } & & $\boldsymbol{B}$ & Std. Error & Beta & & \\
\cline { 3 - 5 } 1 & (Constant) & 0,170 & 0,227 & & 0,747 & 0,457 \\
& X1 & 0,383 & 0,048 & 0,437 & 8,054 & 0,000 \\
& X2 & 0,796 & 0,048 & 0,835 & 16,721 & 0,000 \\
& X3 & $-0,301$ & 0,086 & $-0,210$ & $-3,503$ & 0,001 \\
\hline
\end{tabular}

BerdasarkanTabel 3, maka persamaan regresi linier berganda sebagai berikut :

$$
Y=0,170+0,383 X_{1}+0,796 X_{2}-0,301 X_{3}
$$

Adapun penjelasan persamaan di atas, dapat dijabarkan bahwa koefisien konstanta sebesar 0,170 menunjukkan bahwa jika variabel informativeness, entertainment, dan irritating dianggap tidak ada, maka nilai Attitude towards Social Media Advertising pada Masyarakat Kota Mataram adalah sebesar 0,170.Selanjutnya akan diuraikan mengenai koefisien regresi dari masing-masing variabel penelitian. 
Nilai koefisien regresi variabel informativeness $\left(X_{1}\right)$, adalah sebesar 0,383 . Artinya jika informativeness berubah 1 skor, maka Attitude towards Social Media Advertising pada Masyarakat Kota Mataram (Y) akan meningkat sebesar 0,383 dengan asumsi variabel lainnya tetap. Koefisien regresi yang bertanda positif menunjukkan pengaruh yang searah antara informativeness dengan sikap. Secara parsial, variabel pengetahuan informativeness mempunyai pengaruh yang signifikan terhadap Attitude towards Social Media Advertising pada Masyarakat Kota Mataram. Hal ini ditunjukkan oleh nilai thitung sebesar 8,054 yang lebih besar dari nilai $t_{\text {tabel }}$ sebesar 1,984. Berdasarkan nilai signifikansi juga dapat dibuktikan dengan nilai yang diperoleh sebesar 0,000, dimana nilai ini lebih kecil dari syarat ketentuan nilai signifikansi sebesar 0,050.Hasil ini mendukung hipotesis 1 penelitian yang berarti bahwa hipotesis pertama terbukti dan dapat diterima.

Nilai koefisien regresi variabel entertainment $\left(\mathrm{X}_{2}\right)$, adalah sebesar 0,796 . Artinya jika entertainment berubah 1 skor, maka Attitude towards Social Media Advertising pada Masyarakat Kota Mataram (Y) akan berubah sebesar 0,796 dengan asumsi variabel lainnya tetap. Koefisien regresi yang bertanda positif menunjukkan pengaruh yang searah antara entertainment dengan sikap masyarakat pengguna aktif media sosial. Secara parsial variabel entertainment mempunyai pengaruh yang signifikan terhadap Attitude towards Social Media Advertising pada Masyarakat Kota Mataram, ditunjukkan dengan nilai thitung sebesar 16,721 yang lebih besar dari nilai $t_{\text {tabel }}$ sebesar 1,984. Selain itu juga dapat dilihat dari nilai signifikansi yang diperoleh variabel kesadaran wajib pajak sebesar 0,000 yang masih berada di bawah nilai ketentuan signifikan sebesar 0,050 . Hasil ini mendukung hipotesis 2 penelitian yang berarti bahwa hipotesis ke-dua terbukti dan dapat diterima.

Nilai koefisien regresi irritating $\left(X_{3}\right)$, adalah sebesar -0,301. Artinya jika irritatingberubah 1 skor, maka Attitude towards Social Media Advertising pada Masyarakat Kota Mataram (Y) akan berubah sebesar 0,301dengan asumsi variabel lainnya tetap. Koefisien regresi yang bertanda negatif menunjukkan pengaruh yang berlawanan arah antara irritating dengan sikap masyarakat pengguna aktif media sosial. Untuk variabel irritating, secara parsial mempunyai pengaruh yang signifikan terhadap Attitude towards Social Media Advertising pada Masyarakat Kota Mataram. Hal ini ditunjukkan oleh nilai $t_{\text {hitung }}$ sebesar $-3,503$ yang lebih kecil dari nilai $-t_{\text {tabel }}$ sebesar $-1,984$. Jika dilihat dari nilai signifikansinya juga lebih besar dari nilai ketentuan signifikan sebesar 5 persen $(0,050)$, dimana diperoleh nilai signifikansi untuk variabel lingkungan sosial sebesar dari 0,001 . Hal ini menerima hipotesis 3 penelitian yang berarti irritating berpengaruh signifikan tehadap Attitude towards Social Media Advertising pada Masyarakat Kota Mataram.

\subsection{Pembahasan}

Berdasarkan hasil analisis regresi linier berganda, maka pada bagian ini dibahas hasil perhitungan yang telah dilakukan. Penelitian ini bertujuan untuk mengetahui pengaruh entertainment, informativeness, dan irritating terhadap Attitude towards Social Media Advertising pada Masyarakat Kota Mataram. Hasil pengujian ditunjukkan melalui uji hipotesis yang ada sehingga dapat mengetahui bagaimana pengaruh masing-masing variabel terhadap variabel sikap.

Berdasarkan hasil penelitian diperoleh bahwa variabel entertainment, informativeness dan irritating memiliki pengaruh yang signifikan terhadap Attitude towards Social Media Advertising pada Masyarakat Kota Mataram. Hal ini didukung dengan hasil analisis koefisien determinasi berganda diperoleh Adjusted $R^{2}$ sebesar 0,807 atau sebesar 80,70 persen. Artinya variabel entertainment, informativeness, dan irritating sebesar 80,70 persen berkontribusi atau memberikan sumbangan dalam membentuk Attitude towards Social Media Advertising pada Masyarakat Kota Mataram. 
Hasil dari uji $\mathrm{F}$ pada analisis regresi linier berganda menunjukkan adanya pengaruh yang signifikan variabel bebas yaitu variabel entertainment, informativeness, dan irritating terhadap Attitude towards Social Media Advertising pada Masyarakat Kota Mataram yang ditunjukkan oleh nilai $\mathrm{F}$ hitung yang lebih besar dari nilai $\mathrm{F}$ tabel. Hasil ini sejalan dengan penelitian yang dilakukan olehAchmad (2014), Budiarto (2014), El Ashmawy dan El Sahn (2014), Le dan Nguyen (2014), Vander Waldt, Rebello dan Brown (2009). Selain itu hasil penelitian ini juga semakin mempertegas teori yang dikemukakan oleh Ducoffe (1996).

Secara parsial masing-masing variabel bebas informativeness, irritation, dan credibility berpengaruh terhadap Attitude towards Social Media Advertising pada Masyarakat Kota Mataram. Hipotesis penelitian bertujuan untuk menguji apakah entertainment, informativeness, dan irritation berpengaruh signifikan terhadap Attitude towards Social Media Advertising pada Masyarakat Kota Mataram. Ketiga variabel yang signifikan mempengaruhi Attitude towards Social Media Advertising pada Masyarakat Kota Mataram telah sesuai dengan teori-teori yang sudah ada maupun penelitian terdahulu yang telah dilakukan oleh beberapa peneliti pemasaran yang fokus meneliti iklan elektronik. Pembahasan mengenai penegasan pembuktian hipotesis dalam penelitian ini akan diuraikan lebih lanjut dalam paragraf berikutnya.

\subsubsection{Pengaruh Entertainment terhadap Attitude Towards Social Media}

Nilai thitung untuk variabel informativeness sebesar 8,054 dengan nilai signifikansi 0,000 yang berarti signifikan pada $p<0,05$, maka dapat disimpulkan bahwa hipotesis yang diajukan dalam penelitian ini dapat diterima. Artinya, secara statistik dapat ditunjukkan bahwa informativeness berpengaruh signifikan terhadap Attitude towards Social Media Advertising pada Masyarakat Kota Mataram.

Berdasarkan analisis data diperoleh hasil bahwa terdapat pengaruh positif atau searah dan signifikan antara variabel informativeness terhadap Attitude towards Social Media Advertising pada Masyarakat Kota Mataram. Hal ini menunjukkan bahwa jika terjadi perubahan baik itu peningkatan ataupun penurunan pada variabel informativeness, maka akan menyebabkan perubahan pula secara searah/berbanding lurus terhadap variabel terikat dalam hal ini adalah sikap masyarakat Kota Mataram pengguna aktif media sosial. Hal ini telah dibuktikan oleh hasil uji $t$ dimana diperoleh nilai $t$ hitung positif yang lebih besar daripada nilai $\mathrm{t}$ tabel dan nilai signifikansi yang lebih kecil dari 0,05 yang menyatakan menolak hipotesis nol dan menerima hipotesis penelitian. Hasil tersebut sangat relevan dengan penelitian terdahulu yang dilakukan olehBudiarto (2014), El Ashmawy dan El Sahn (2014), Le dan Nguyen (2014).

\subsubsection{Pengaruh Informativeness terhadap Attitude Towards Social Media}

Nilai t hitung untuk variabel entertainment sebesar 16,721 dengan nilai signifikansi 0,000 yang berarti signifikan pada $\mathrm{p}<0,05$, maka dapat disimpulkan bahwa hipotesis yang diajukan dalam penelitian ini dapat diterima. Artinya, secara statistik ditunjukkan bahwa entertainment berpengaruh signifikan terhadap Attitude towards Social Media Advertising pada Masyarakat Kota Mataram.

Berdasarkan analisis data diperoleh hasil bahwa terdapat pengaruh positif atau searah dan signifikan antara variabel entertainment terhadap Attitude towards Social Media Advertising pada Masyarakat Kota Mataram. Hal ini menunjukkan bahwa jika terjadi perubahan baik itu peningkatan ataupun penurunan pada variabel entertainment, maka akan menyebabkan perubahan pula secara searah/berbanding lurus terhadap variabel terikat dalam hal ini adalah sikap masyarakat Kota Mataram pengguna aktif media sosial. Hal ini telah dibuktikan oleh hasil uji $\mathrm{t}$ dimana diperoleh nilai $\mathrm{t}$ hitung positif yang lebih besar daripada nilai $t$ tabel dan nilai signifikansi yang lebih kecil dari 0,05 yang jmm.unram.ac.id 
menyatakan menolak hipotesis nol dan menerima hipotesis penelitian. Hasil tersebut sangat relevan dengan penelitian terdahulu yang dilakukan oleh El Ashmawy dan El Sahn (2014) serta penelitian Le dan Nguyen (2014).

4.2.3. Pengaruh Irritating terhadap Attitude Towards Social Media

Variabel irritating dengan nilai t hitung sebesar -3,503 dengan nilai signifikansi 0,001 yang berarti signifikan pada $\mathrm{p}<0,05$, maka dapat disimpulkan bahwa hipotesis yang diajukan dalam penelitian ini dapat diterima. Artinya, secara statistik ditunjukkan bahwa irritating berpengaruh negatif dan signifikan terhadap Attitude towards Social Media Advertising pada Masyarakat Kota Mataram. Dengan demikian hipotesis dalam penelitian ini terdukung sepenuhnya (fully supported).

Variabel irritating berpengaruh signifikan dan negatif terhadap Attitude towards Social Media Advertising pada Masyarakat Kota Mataram dimana hal ini berarti bahwa semakin tinggi tingkat variabel irritating dalam iklan berbasis media sosial akan menurunkan sikap masyarakat pengguna aktif media sosial. Begitu juga sebaliknya, semakin rendah tingkat irritating dalam iklan berbasis media sosial akan meningkatkan sikap masyarakat pengguna aktif media sosial terhadap iklan tersebut. Hasil penelitian juga mendukung temuan dalam penelitian Budiarto (2014), El Ashmawy dan El Sahn (2014), Le dan Nguyen (2014), Vander Waldt, Rebello dan Brown (2009), dimana dalam penelitian mereka mendapatkan hasil yang sama yaitu variabel irritating berpengaruh signifikan dan negatif terhadap sikap masyarakat.

\section{KESIMPULAN DAN SARAN}

Variabel informativeness berpengaruh positif dan signifikan terhadap Attitude towards Social Media Advertising pada Masyarakat Kota Mataram. Variabel entertainment secara individual berpengaruh positif dan signifikan terhadap Attitude towards Social Media Advertising pada Masyarakat Kota Mataram, variabel entertainment merupakan variabel yang dominan mempengaruhi sikap masyarakat Kota Mataram, hal ini dibuktikan oleh nilai standardize coefficient betayang terbesar pada variabel entertainment. Variabel irritating berpengaruh signifikan dengan arah negatif terhadap Attitude towards Social Media Advertising pada Masyarakat Kota Mataram.

Dari analisis pembahasan dan kesimpulan, maka dapat dikemukakan saran dimana Attitude toward Social Media Advertising dapat ditingkatkan dengan meningkatkan entertainment pada iklan yang disampaikan. Entertainment dapat ditingkatkan dengan cara iklan yang disampaikan mengandung unsur hiburan yang dapat memberikan kesan di hati konsumen, iklan yang disampaikan lebih menarik dari iklan lain yang disampaikan melalui media sosial. Selain itu iklan berbasis media sosial harus mampu memberikan kesenangan pada masyarakat pengguna aktif media sosial selaku konsumen potensial baik saat melihat iklan maupun saat menggunakan produk/jasa yang diiklankan.

Bagi praktisi periklanan di Kota Mataram disarankan untuk terus meningkatkan kualitas informasi yang disampaikan dalam iklan, menampilkan daya tarik yang lebih menyita perhatian calon konsumen produk yang diiklankan, serta menghilangkan hal-hal yang kira-kira dapat mengurangi dampak positif tujuan periklanan.

Keterbatasan di dalam penelitian ini adalah responden yang dijadikan penelitian hanya pada masyarakat Kota Mataram. Karena keterbatasan dana dan waktu, jumlah sampel yang diteliti kurang menggambarkan populasi pengguna media sosial secara umum. Hal ini dapat dilihat dari penyebaran umur responden dan jenis kelamin responden. Jadi sampel kurang acak, sehingga hasil kurang maksimal. Penelitian ini hanya 
dilakukan di Kota Mataram, sehingga kurang representatif terhadap jumlah populasi pengguna media sosial yang ada di Pulau Lombok. Selain itu penelitian ini dilakukan dengan menggunakan indikator variabel yang terbatas. Peneliti tidak meneliti indikator variabel lainnya yang memiliki kontribusi dalam membentuk Attitude toward Social Media Advertising.

\section{DAFTAR PUSTAKA}

Ajzen, I. and Fishbein, M. (1980). Understanding Attitudes and Predicting Social Behavior, Prentice-Hall, Englewood Cliffs, NJ.

Bgamal, "Why advertising on social network doesn't work", Blog (Online), Available at: http://hubpages.com/hub/Why-Social-Network-Advertising-Doesnt-Work (Accessed on February 2019)

Bowling, A. (1997). Research Methods in Health. Buckingham: Open University Press.

Brackett, L. K., \& Carr Jr., B. N. (2001). “Cyberspace advertising vs. other media: Consumer vs. mature student attitudes". Journal of Advertising Research, 41(5), 23-33.

Burns, N., \& Grove, S. K. (1997). The Practice of Nursing Research Conduct, Critique, E Utilization. Philadelphia: W.B. Saunders and Co.

Cho, C. (2004). "Why do people avoid advertising on the internet?", Journal of Advertising, Vol. 33 No. 4, pp. 89-97.

Cholid Narbuko dan Abu Ahmadi, 2001, "Metode Penelitian", Bumi Aksara, Jakarta

Chowdhury HK, Parvin N, Weitenberner C, Becker M. (2006). Consumer Attitude toward Social Media Advertising in Emerging Market: An Empirical Study. International Journal Mobile Marketing, Vol. 1, No. 2, pp. 33-42.

Ducoffe. (1996). "Advertising Value and Advertising on the Web", Journal of ADVERTISING Research - September/October.

Eagly, A.H. and Chaiken, S. (1993). The Psychology of Attitudes, Harcourt, Brace \& Jovanovich College Publishers, Fort Worth, TX.

Ford, K. (2008). "How is social media changing the face of marketing", Hoover's WhitePaper: A Guide to Marketing in the Age of Social Media", Hoover's, Inc., (Online), Available at: http://www.scribd.com/doc/8979019/Hoovers-Whitepaper-How-is-Social-MediaChanging-the-Face-of-Marketing-By-Katie-Ford

Hasan, I. (2002). Pokok - Pokok Materi Teori Pengambilan Keputusan. Ghalia Indonesia: Jakarta.

Keng, C. and Ting, H. (2009). "The acceptance of blogs: using a customer experiential value perspective", Internet Research, Vol. 19 No. 5, pp. 479-495.

Kotler P. (2003). "Marketing Management". Pearson Education, Upper Saddle River, New Jersey.

Lutz, Richard J. (1985). "Affective and Cognitive Antecedents of Attitude toward the Ad: A Conceptual Framework, "in Psychological Processes and Advertising Effects", ed. Linda Alwitt and Andrew Mitchell, Hillsdale, NJ: Erlbaum, 45-63.

MacKenzie, S.B., Lutz, R.J. and Belch, G.E. (1986). "The role of attitude toward the ad as a mediator of advertising effectiveness: a test of competing explanations", Journal of Marketing Research, Vol. 23 No. 2, pp. 130-143.

Mittal, B. (1994). "Public assessment of TV advertising: faint praise and harsh criticism", Journal of Advertising Research, Vol. 34 No. 1, pp. 35-53.

Muehling, D.D. (1987). "An investigation of factors underlying attitude-towardadvertising-ingeneral", Journal of Advertising, Vol. 16 No. 1, pp. 32-40. 
Porter, J. (2008). "Why social ads won't work”, Blog (Online) Available at:http://bokardo.com/archives/why-social-ads-dont-work/ (accessed on February 2019).

Richards J, Curran C. (2002). Oracles on Advertising: Searching for a Definition. Journal Advertising, Vol. 31, No. 2, pp. 63-77.

Saadeghvaziri F, Hosseini H.K. (2011). Social Media Advertising: An Investigation of Factors Creating Positive Attitude in Iranian Customers. African Journal of Business Management, Vol. 5, No. 2, pp. 394-404.

Santoso. (2005). Metode Suatu Penelitian. Jakarta. Rineka Aksara.

Scharl, A., Dickinger, A. and Murphy, J. (2005). "Diffusion and success factorsof mobile marketing", Electronic Commerce Research and Applications, Vol. 4 No. 2, pp. 159173.

Shavitt, S., Lowrey, P. M. \& Haefner, J. E. (1998). Public Attitudes Toward Advertising : More Favorable Than You Might Think. Journal of Advertising Research, 7-22.

Stern, A. (2008). "My life on Facebook as a woman and why social network advertising doesn't work", Blog (Online) Available at: http://www.centernetworks.com/socialnetwork-advertising (accessed on December 2018)

Suryabrata, S. (2010). Metodologi Penelitian. Jakarta: Raja Grafindo Persada.

Tsang MM, Ho SH, Liang TP. (2004). Consumer Attitudes toward Social Media Advertising: An Empirical Study. International Journal Electronic Communication, Vol. 8, No. 3, pp. 65-78.

Uphoff, T. (2009). "Advertising doesn't work on social network", Blog (Online),Available at: http://www.uphoffonmedia.com/uphoffonmediacom/2009/2/8/advertisingdoesntwork-on-social-networks.html (Accessed on February 2019)

Waldt DLRVD, Rebbello TM, Brown WJ. (2009). Attitude of Young Consumers toward SMS Advertising. African Journal of Bussiness Management, Vol. 3, No. 9, pp. 444-452. 